\title{
Autoimmune Myopathies: Where Do We Stand?
}

\author{
Jean-Philippe Simon ${ }^{1,2}$, Isabelle Marie ${ }^{2}$, Fabienne Jouen ${ }^{2}$, Olivier Boyer ${ }^{2 *}$ and \\ Jérémie Martinet ${ }^{2}$ \\ ${ }^{1}$ Laboratory of Neuropathology, CHU Caen, Normandie University, UNICAEN, Caen, France, ${ }^{2}$ Normandie University, \\ UNIROUEN, Pathophysiology and Biotherapy of Inflammatory and Autoimmune Diseases, INSERM, CHU Rouen, Rouen, \\ France
}

Autoimmune diseases (AIDs) as a whole represent a major health concern and remain a medical and scientific challenge. Some of them, such as multiple sclerosis or type 1 diabetes, have been actively investigated for many decades. Autoimmune myopathies (AIMs), also referred to as idiopathic inflammatory myopathies or myositis, represent a group of very severe AID for which we have a more limited pathophysiological knowledge. AlM encompass a group of, individually rare but collectively not so uncommon, diseases characterized by symmetrical proximal muscle weakness, increased serum muscle enzymes such as creatine kinase, myopathic changes on electromyography, and several typical histological patterns on muscle biopsy, including the presence of inflammatory cell infiltrates in muscle tissue. Importantly, some AIMs are strongly related to cancer. Here, we review the current knowledge on the most prevalent forms of AIM and, notably, the diagnostic contribution of autoantibodies.

Keywords: myositis, necrotizing myopathy, autoantibodies, inclusion-body myositis, dermatomyositis

Norbert Sommer

Hospital Christophsbad, Germany

Anne Schänzer,

Justus Liebig University Gießen,

Germany

${ }^{*}$ Correspondence:

Olivier Boyer

olivier.boyer@chu-rouen.fr

Specialty section:

This article was submitted to Multiple Sclerosis and Neuroimmunology,

a section of the journal

Frontiers in Immunology

Received: 25 March 2016

Accepted: 31 May 2016

Published: 14 June 2016

Citation:

Simon J-P, Marie I, Jouen F, Boyer O and Martinet J (2016) Autoimmune

Myopathies: Where

Do We Stand?

Front. Immunol. 7:234.

doi: 10.3389/fimmu.2016.00234

Bohan and Peter originally classified myositis into two major groups based on clinical, electromyographical, and immunohistological features: polymyositis (PM) and dermatomyositis (DM), the latter associating skin manifestations to muscle weakness (1). Indeed, the presence of a muscle inflammatory infiltrate is a hallmark in autoimmune myopathies (AIM), but it is not discriminating enough since it cannot per se identify each AIM subtype and maybe present in some types of muscular dystrophies. Sporadic inclusion-body myositis (sIBM), resistant to steroids and associating both autoimmune and degenerative components, was individualized more recently $(2,3)$. When defined according to the Bohan and Peter classification, PM was initially considered as the archetype of AIM, although it seems to be an uncommon pathological entity, some experts even arguing that it barely exists $(4,5)$. Indeed, according to newer, more stringent criteria, most AIM initially diagnosed as PM were reclassified as overlap myositis $(\mathrm{OM})$, a condition with not only musculoskeletal but also extramuscular involvement and/or association to autoantibodies (aAbs) (6). Anti-tRNA synthetase syndrome (ARS syndrome) is the archetype of OM combining myositis to interstitial lung disease, arthritis, Raynaud phenomenon, and mechanic's hands. Hence, ARS syndrome has been considered by some authors as an atypical clinical form of DM (7). OM and DM are the more frequent AIM (67 and 18\%, respectively, according to Troyanov et al.) (6). Around $60 \%$ of patients with AIM have myositis-specific aAbs (8), and it is presumable that this frequency will reach higher levels when appropriate diagnostic immunoassays are more widely used and new specificities are discovered (Figure 1). The more recently identified entity is represented by necrotizing autoimmune myopathies (NAM), also sometimes referred to as immune-mediated necrotizing myopathies. This group of severe AIM is characterized by minimal inflammatory infiltrate but predominant necrotic 


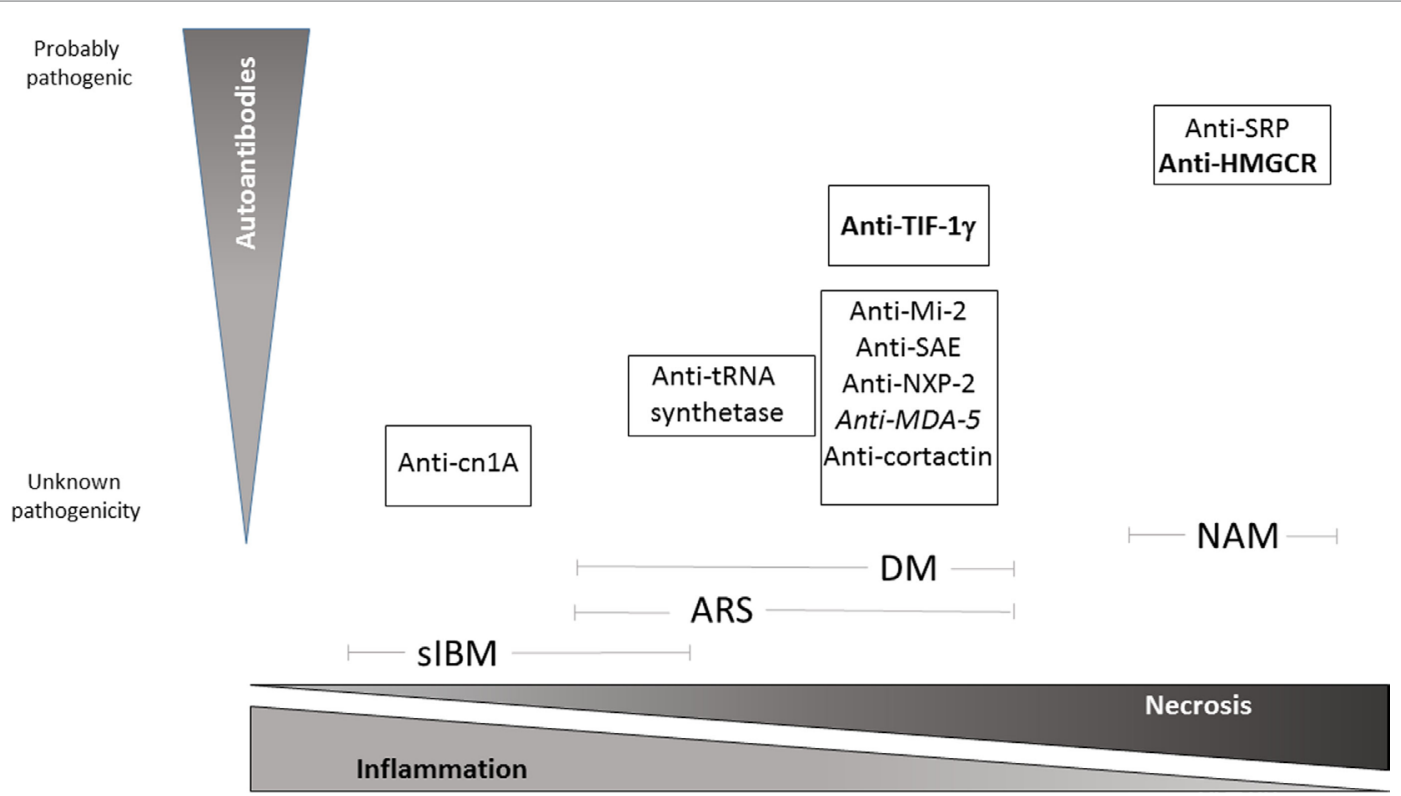

FIGURE 1 | Schematic view of pathological pattern of inflammatory myopathies and proven degree of pathogenicity of specific autoantibodies relative to each IM subtypes. Bold: high risk of neoplasia, Italics: amyopathic DM. NAM, necrotizing autoimmune myopathy; DM, dermatomyositis; ARS, anti-t-rna synthetase syndrome; sIBM, sporadic inclusion-body myositis.

fibers on muscle biopsy (9). The discovery of aAbs directed to components of the signal recognition particle (SRP) (10) or to 3-hydroxy-3-methylglutaryl-coenzyme A reductase (HMGCR) $(11,12)$ has been instrumental in identifying this entity.

\section{DERMATOMYOSITIS AND OVERLAP MYOSITIS}

Dermatomyositis affects both children and adults, most frequently women, and is associated with cancer in adults and calcinosis in children. The clinical presentation of DM includes skin manifestations that usually precede muscle weakness (13). Skin features are varied and some are very specific such as a violaceous eruption (Gottron's rash) on the knuckles which may evolve into a scaling discoloration (Gottron's papule), purple periorbital heliotrope rash with edema notably on upper eyelids, while others are less specific as erythematous rash on the face, knees, elbows, malleoli, neck, anterior chest (in a V-sign), back and shoulders (in a shawl sign), or periungeal erythema, painful to pressure (manicure sign) (14). Muscle weakness constantly involves limb girdle muscles and less frequently respiratory and pharyngeal muscles (15).

As a consequence of myofiber injury, creatine kinase is released and found elevated in the serum. Electromyography and MRI may also be useful to evaluate disease topography and guide muscle biopsy. In the presence of typical skin manifestations, muscle biopsy is not always performed. When it is the case, histological analysis establishes the diagnosis by showing features that, in addition to inflammation and myofiber necrosis plus regeneration, distinguish DM from other myositis pattern: endomysial microangiopathy with membrane attack complex (C5b-9) capillaries staining and ischemic fiber lesions. Also, in DM, mononuclear cells composed of macrophages, B lymphocytes, and plasmacytoid dendritic cells ( $\mathrm{pDC}$ ) predominantly infiltrate perivascular and perimysial areas (Figure 2A), whereas normal muscle fibers do not express detectable levels of HLA class I molecules $(16,17)$, sarcolemmal re-expression of HLA class I is a hallmark of most types of myositis, with a perifascicular enhancement, in the case of DM (15). Recently, a lymphoid follicle variant of juvenile DM has been described and is associated with a severe prognosis (18).

Several aAbs are associated with different clinical forms of DM and have an impact on the prognosis (19). Anti-Mi2 aAbs are positive in $10-20 \%$ of DM and associated with a low risk of associated cancer and a better prognosis (20). Anti-Mi2 aAbs are directed against the nucleosome remodeling histone-deacetylase (NURD) nuclear protein complex, implicated in DNA transcription. In contrast, anti-TIF1 $\gamma$ aAbs are positive in more than $10 \%$ of $\mathrm{DM}$ and the presence of this $\mathrm{aAb}$ is highly associated with cancer (21). As in other DM, transcription intermediary factor 1 (TIF1) family proteins, a nuclear transcription factor (22), is implicated in the TGF $\beta$ pathway (23). Anti-melanoma differentiation-associated gene 5 (anti-MDA-5) aAbs recognize an innate immune protein implicated in antiviral response and is positive in about $10-20 \%$ of DM (24). They are more frequent in amyopathic forms of DM, with severe interstitial lung disease and ulceral lesions (25). Anti-NXP-2 aAbs are more frequent in juvenile DM and are associated with calcinosis. Others, such as anti-small ubiquitin-like modifier activating enzyme (anti-SAE) $(26,27)$ or anti-cortactin $(28)$, are currently found more rarely and also less routinely sought for. 


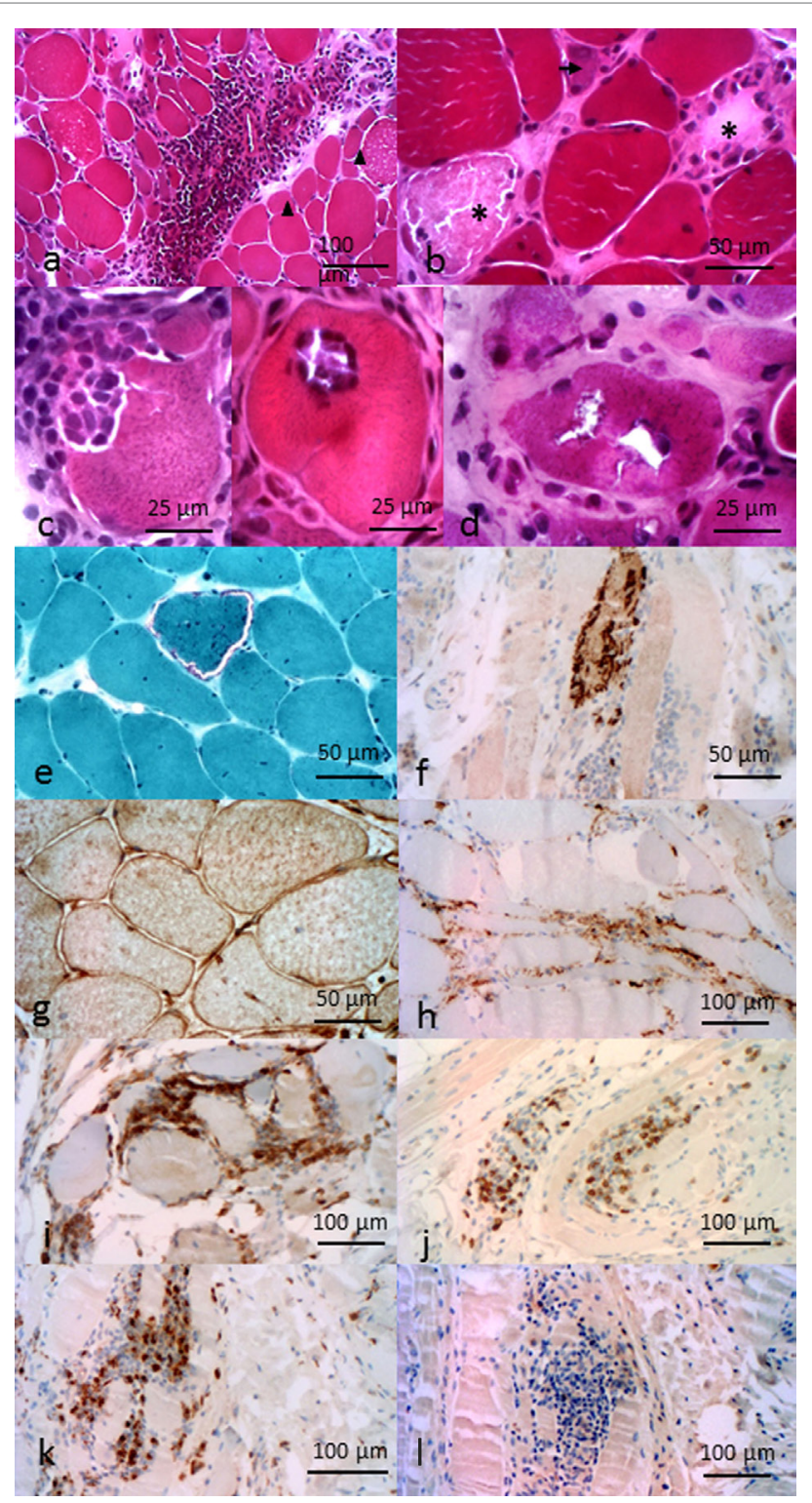

FIGURE 2 | Pathological features of inflammatory myopathies.

Pathological features of DM. (A) Perimysial and perivascular inflammatory cell infiltrate. Perifascicular myofiber atrophy (arrow heads). Pathological features of anti-HMGCR NAM. (B) Necrotic (asterisk) and regenerative (arrows) myofibers, sparsely infiltrate pathological features of sIBM. (C) Invaded fibers by inflammatory cells. (D) Rimmed vacuoles. (E) Ragged-red fiber. (F) P62 aggregates. (G) Immunohistochemichal evidence of MHC-I myofibers expression. (H) C5b-9 membrane attack complex in capillaries. Composition of the endomysial inflammatory infiltrate (I) $\mathrm{CD}^{+}$cells, (J) $\mathrm{CD} 8^{+}$cells, (K) $\mathrm{CD}^{+} 8^{+}$cells, and (L) rare CD20+ cells. All features provided by Dr. JeanPhilippe Simon.

The physiopathology of DM is not well understood $(13,29)$. Muscle biopsy shows not only immune cells infiltrates but also C5b-9 deposits. Since DM is strongly associated with the presence of aAbs, it is presumable, yet not clearly demonstrated, that these aAbs may activate complement triggering the release of pro-inflammatory cytokines, upregulation of adhesion molecules on endothelial cells, and migration of $\mathrm{B}$ and $\mathrm{CD} 4^{+} \mathrm{T}$ lymphocytes and pDC (30-32). Type 1 interferons produced by pDC, in turn, stimulate the production of pro-inflammatory cytokines and enhance the expression or HLA class I and class II molecules (33).

Dermatomyositis associated with anti-TIF $1 \gamma$ aAbs is strongly related to cancer (21). One (non-demonstrated) hypothesis is that somatic mutations in cancer cells may have occurred in the TIF1 $\gamma$ gene, yielding to the production of an immunogenic nonself neoantigen, which could lead to autoimmunity after epitope spreading of the B cell response, following the example of POLR3 mutations in systemic sclerosis (34). This hypothesis would imply that anti-TIF1 $\gamma$ aAbs and/or T cells are directly pathogenic, which remains to be demonstrated.

High-dose oral corticosteroids (1 $\mathrm{mg} / \mathrm{kg}$ ) represent the first-line treatment in DM $(13,35)$. Methylprednisolone bolus (500 mg/day-1 g/day during 3 days) can be considered when severe motor deficit or life-threatening extramuscular manifestations are present. Immunosuppressive treatments are used as second-line treatment (methotrexate, azathioprine) if corticosteroid treatment is ineffective or if the patient has developed serious corticosteroid-related side effects. Others treatment can be considered as third-line therapy (36): intravenous immunoglobulins, ciclosporin, cyclophosphamide, or rituximab.

Anti-tRNA synthetase syndromes are defined by aAbs positivity directed against one aminoacyl-tRNA synthetase enzyme. ARS syndrome has been initially described as a specific clinical presentation regrouping myositis, lung interstitial disease, arthritis, mechanic's hands, and Raynaud phenomenon. There is some clinical variation depending on the aAb. Patients may initially present with an isolated lung involvement. This syndrome is associated with specific aAb directed against one of the aminoacyl-tRNA-synthetase enzymes that enable tRNA to bind to specific amino acids. Each enzyme is specific for an amino acid/tRNA pair (37). The most common aAbs, by far, recognize histidyl-tRNA-synthetase (anti-JO-1), others less frequently alanyl-tRNA-synthetase (anti-PL-12) or threonyltRNA-synthetase (anti-PL-7). The pathological pattern is close to that of DM (38). Recent pathological studies argue for some specific features, such as a HLA-DR expression, with a specific perifascicular pattern (39), as the topography of necrotic myofibers (40), ARS syndrome usually respond to corticosteroids and immunosuppressive drugs. Rituximab can be considered in case of severe muscular weakness or intestitial lung disease $(41,42)$.

\section{NECROTIZING AUTOIMMUNE MYOPATHIES}

Although their frequency is difficult to determine precisely at this stage, NAM probably account for $20 \%$ of AIM. They mainly affect adults, most frequently women. NAM clinical presentation is characterized by symmetrical and proximal muscle weakness leading to muscle atrophy, which can be associated with interstitial lung disease, dysphagia, or dyspnea $(43,44)$. Some patients present with progressive, corticosteroid resistant myositis, while other forms may masquerade as a muscular dystrophy, yielding to a delay in diagnosis. 
Creatine kinase is generally highly elevated $(>4,000 \mathrm{U} / \mathrm{L})$ and correlated with disease severity during follow-up (10, 45, 46). Electrocardiogram may be abnormal $(13,47)$. Muscle MRI can be useful to confirm muscle involvement, evaluate disease topography, and guide the biopsy.

The prominent histological finding in NAM is the presence of necrotic and regenerative myofibers. Atrophic and irregularly shaped myofibers are also present (Figure 2B). When present, inflammatory infiltrates are mostly composed of macrophages $(48,49)$. Yet, a mild lymphocytic infiltrate can be found in some patients with presence of $\mathrm{CD}^{+}$and $\mathrm{CD} 8^{+} \mathrm{T}$ cells, B cells, and dendritic cells restricted to the perivascular and endomysial regions. C5b-9 deposits can be found on necrotic myofibers, sarcoplasm of myofibers, and in some capillaries (50). As opposed to other AIM, HLA class I re-expression is mild and scattered, if present (43).

Necrotizing autoimmune myopathies are strongly associated with specific aAbs in two-third of cases: anti-SRP or anti-HMGCR aAbs. Anti-SRP aAbs mainly, but not exclusively, target the $54 \mathrm{kDa}$ subunit of the SRP complex localized in the cytoplasm or at the surface of the endoplasmic reticulum, when bound to the SRP receptor. SRP allows the transfer of nascent proteins to the endoplasmic reticulum during protein synthesis. Anti-SRP aAbs from patients are able to block this mechanism $(51,52)$. Younger patients with anti-SRP aAbs may develop a form mimicking a muscular dystrophy (53). Anti-HMGCR aAbs target the catalytic domain of hydroxyl-methylglutaryl-coenzyme A reductase. This endoplasmic reticulum membrane enzyme is involved in the biosynthesis of cholesterol and is the pharmacological target of the hypocholesterolemic drugs, statins $(11,54)$. We developed quantitative immune-assays based on the ALBIA/Luminex technology, which showed that anti-SRP and anti-HMGCR aAbs levels correlate with disease activity, as evaluated by CK levels and muscle strength (10, 45). One-third of NAM patients still do not exhibit known aAbs, but it is anticipated that new specificities will be discovered.

Necrotizing autoimmune myopathies pathophysiology is still poorly understood, notably because of a lack of animal models. An autoimmune mechanism has been early suggested by the association between NAM and the above-mentioned anti-SRP aAbs (50, 55). It should be reminded that both anti-SRP and anti-HMGCR aAbs target intracellular proteins and the question of how they may reach their cognate antigen remains a mystery. However, the paucity of inflammatory infiltrate, the mild re-expression of HLA class I by non-necrotic and non-regenerative myofibers, and the pathogenic implication of antibodies suggested by the correlation between level of aAbs and disease activity strongly argues for a humoral-related disease with aAb-dependent complementmediated myofiber attack, eventually leading to myofiber necrosis and regeneration from satellite cells $(11,45,54,56)$. The presence of C5b-9 deposits on muscle cells further supports the hypothesis of a direct role of anti-SRP and anti-HMGCR aAbs. Approximately half of anti-HMGCR positive NAM patients have been exposed to statins, molecule that inhibit activity and provoke overexpression of HMGCR $(11,54)$. It cannot be excluded that the binding of a statin to HMGCR might also change the conformation of the protein, leading to the generation of new epitopes to which the immune system would not be tolerant (44).
We have some experimental evidence suggesting that anti-SRP and anti-HMGCR aAbs are directly pathogenic in vitro on muscle cells and in vivo in mice.

Currently, there is no validated therapeutic strategy for NAM. High-dose oral corticosteroids $(1 \mathrm{mg} / \mathrm{kg})$ are the first line of treatment (47). However, they are not sufficient to control disease and need to be combined with immunosuppressive therapy (methotrexate, azathioprine, and cyclosporine) and intravenous immunoglobulins $(44,57,58)$. In resistant patients, due to the presumable pathogenic role of aAbs, plasmapheresis can be helpful and lead to clinical improvement. Also, some studies have shown the interest to treat patients with rituximab $(50,59)$ or cyclophosphamide (60). A recent study has evidenced an association between anti-HMGCR positive and seronegative NAM to neoplasia, whereas anti-SRP positive NAM was not related to cancer (61). This study also showed that the presence of cancer is a main determinant of outcome. In case of exposure, statin treatment must be immediately discontinued. Statin exposed patients seem to have a better response to treatment $(45,62)$. Finally, it should be stated that statins may be present in the food (some mushrooms or yeast for instance) and patients could have been exposed without being aware of it. Therefore, absence of statin exposure should not discard this diagnosis.

\section{SPORADIC INCLUSION-BODY MYOSITIS}

Sporadic inclusion-body myositis is the most frequently acquired myopathy in patients over 50 years (63). Its natural course is quite slow with a progressive muscular weakness worsening year after year often leading to a loss of ambulation, respiratory muscle weakness, and dysphagia (3). sIBM affect striated muscle with a characteristic pattern affecting quadriceps, fingers deep flexors, and possibly pharyngeal muscles.

Pathological criteria have been of major importance to retain the diagnosis of sIBM (2). The new criteria no longer require bringing together all the pathological hallmarks (64): they include presence of inflammatory infiltrates (Figure 2C) with mononuclear cell invasion of non-necrotic muscle fibers (partial invasion), vacuolated muscle fibers (Figure 2D), and intracellular amyloid protein deposits or 15-18 nm tubulofilaments in the cytoplasm or the nucleus by electron microscopy. Pathological marks have been historically divided between inflammatory and degenerative signs. Degenerative signs are based on the presence of abnormal accumulation of $\beta$-amyloïdogenic deposits (65-67). These deposits are located in the muscle fibers of sIBM patients, whereas they used to be observed extracellularly in Alzheimer's diseases. Others proteins known to be implicated in degenerative processes have been found, such as ubiquitin (68). The two main pathways of protein degradation, 26S-proteasome (69) and autophagy (70), are impaired, the latter generating rimmed vacuoles. Proteins linked to these pathways are accumulated, as demonstrated by immunostaining, such as p62 or TDP43 (Figure 2F); they represent sensitive pathological markers of $\operatorname{sIBM}(71,72)$. On the other hand, inflammatory infiltrates also accompany these degenerative signs. They are predominantly composed of $\mathrm{CD} 8^{+} \mathrm{T}$ cells and macrophages and a minority of $\mathrm{CD}^{+} \mathrm{T}$ cells and $\mathrm{CD} 20^{+} \mathrm{B}$ cells (Figures $2 \mathrm{I}-\mathrm{L}$ ). $\mathrm{CD} 8^{+} \mathrm{T}$ 
cells and macrophages can invade non-necrotic muscle fibers (73). HLA class I molecules have a diffuse and high overexpression at the sarcolemma $(16,74)$, typically more intense than in other AIMs (Figure 2G). It is presumable that these HLA molecules can present yet unknown muscle auto-antigens to $\mathrm{CD}^{+} \mathrm{T}$ cells. Complement C5b9 membrane attack complex is usually pathologically expressed by capillaries (Figure $\mathbf{2 H}$ ). Moreover, Pestronk recently identified mitochondrial abnormalities (COX negative and/or ragged-red fibers; Figure 2E) as hallmarks of sIBM pathological pattern (38). Yet, despite these signs of probable autoimmunity, sIBM patients respond poorly to immune treatments (3).

The fundamental question remains as to whether sIBM is primarily an inflammatory or degenerative myopathy. We and others have defended elsewhere the view that the starter of SIBM is more likely to be inflammation within muscle (75). Indeed, there are few arguments to consider that degeneration could be the initial event. The strongest would be the lack of efficiency of immunosuppressive drugs (76-79), although two trials assessing massive immunosuppression have reported a strength stabilization (80, 81). Also, the initially selective muscular pattern (quadriceps and fingers deep flexors) is rather a genetic myopathy trait. It should be mentioned here that hereditary IBM (hIBM) may be secondary to mutation in the valosin-containing protein $(V C P)(82,83)$ or UDP- $N$-acetylglucosamine-2-epimerase/ $N$-acetylmannosamine kinase (GNE) (84) gene. Yet, hIBM pathological patterns only contain degenerative elements and no immune infiltrates, indicating that muscle degeneration per se is probably not sufficient to elicit a myositis process. Alternatively, more arguments can be found to support inflammation as an initial trigger. They include association of sIBM to other autoimmune diseases (AIDs) (85), to aAbs directed against cytosolic $5^{\prime}$-nucleotidase1A $(86,87)$, or

\section{REFERENCES}

1. Bohan A, Peter JB. Polymyositis and dermatomyositis (first of two parts). N Engl J Med (1975) 292:344-7. doi:10.1056/NEJM197502132920706

2. Griggs RC, Askanas V, DiMauro S, Engel A, Karpati G, Mendell JR, et al. Inclusion body myositis and myopathies. Ann Neurol (1995) 38:705-13. doi:10.1002/ana.410380504

3. Benveniste O, Guiguet M, Freebody J, Dubourg O, Squier W, Maisonobe T, et al. Long-term observational study of sporadic inclusion body myositis. Brain (2011) 134:3176-84. doi:10.1093/brain/awr213

4. Amato AA, Griggs RC. Unicorns, dragons, polymyositis, and other mythological beasts. Neurology (2003) 61:288-9. doi:10.1212/WNL.61.3.288

5. van der Meulen MF, Bronner IM, Hoogendijk JE, Burger H, van Venrooij WJ, Voskuyl AE, et al. Polymyositis: an overdiagnosed entity. Neurology (2003) 61:316-21. doi:10.1212/WNL.61.3.316

6. Troyanov Y, Targoff IN, Tremblay JL, Goulet JR, Raymond Y, Senecal JL. Novel classification of idiopathic inflammatory myopathies based on overlap syndrome features and autoantibodies: analysis of 100 French Canadian patients. Medicine (Baltimore) (2005) 84:231-49. doi:10.1097/01. md.0000173991.74008.b0

7. Troyanov Y, Targoff IN, Payette MP, Raynauld JP, Chartier S, Goulet JR, et al. Redefining dermatomyositis: a description of new diagnostic criteria that differentiate pure dermatomyositis from overlap myositis with dermatomyositis features. Medicine (Baltimore) (2014) 93:318-32. doi:10.1097/ MD.0000000000000222

8. Mammen AL. Autoimmune myopathies: autoantibodies, phenotypes and pathogenesis. Nat Rev Neurol (2011) 7:343-54. doi:10.1038/nrneurol. 2011.63 to some HLA alleles (88). Also, exposure of human myotubes to IL- $1 \beta$ causes intracellular aggregation of $\beta$-amyloid (89).

\section{SUMMARY}

Autoimmune myopathy represents a group of severe inflammatory diseases. The search for aAbs has substantially improved their diagnosis and may also inform on their prognosis, notably when there is an associated risk of cancer. Studying myositis offers exciting pathophysiological and clinical research perspectives in immunology. Important issues relate to the nature of the association between cancer and adult DM, the pathogenicity of aAbs in NAM, the elucidation of the primum movens of sIBM, the identification of new aAbs and therapeutic targets, and the validation of therapeutic protocols using immunosuppressants or biodrugs. Clearly, the development of appropriate animal models will be instrumental in this perspective.

\section{AUTHOR CONTRIBUTIONS}

OB gave an oral communication on this topic at Immunocolombia 2015 and coordinated the redaction of this mini review. JM and JPS wrote the first draft of this article. JPS designed figures. IM and FJ critically reviewed the manuscript for important intellectual content. All authors approved the final version.

\section{FUNDING}

This work was funded in part by the Association Française contre les Myopathies.

9. Hoogendijk JE, Amato AA, Lecky BR, Choy EH, Lundberg IE, Rose MR, et al. 119th ENMC international workshop: trial design in adult idiopathic inflammatory myopathies, with the exception of inclusion body myositis, 10-12 October 2003, Naarden, The Netherlands. Neuromuscul Disord (2004) 14:337-45. doi:10.1016/j.nmd.2004.02.006

10. Benveniste O, Drouot L, Jouen F, Charuel JL, Bloch-Queyrat C, Behin A, et al. Correlation of anti-signal recognition particle autoantibody levels with creatine kinase activity in patients with necrotizing myopathy. Arthritis Rheum (2011) 63:1961-71. doi:10.1002/art.30344

11. Mammen AL, Chung T, Christopher-Stine L, Rosen P, Rosen A, Doering KR, et al. Autoantibodies against 3-hydroxy-3-methylglutaryl-coenzyme A reductase in patients with statin-associated autoimmune myopathy. Arthritis Rheum (2011) 63:713-21. doi:10.1002/art.30156

12. Drouot L, Allenbach Y, Jouen F, Charuel JL, Martinet J, Meyer A, et al. Exploring necrotizing autoimmune myopathies with a novel immunoassay for anti-3-hydroxy-3-methyl-glutaryl-CoA reductase autoantibodies. Arthritis Res Ther (2014) 16:R39. doi:10.1186/ar4468

13. Dalakas MC. Inflammatory muscle diseases. N Engl J Med (2015) 373:393-4. doi:10.1056/NEJMc1506827

14. Iaccarino L, Ghirardello A, Bettio S, Zen M, Gatto M, Punzi L, et al. The clinical features, diagnosis and classification of dermatomyositis. J Autoimmun (2014) 4(8-49):122-7. doi:10.1016/j.jaut.2013.11.005

15. Dalakas MC, Hohlfeld R. Polymyositis and dermatomyositis. Lancet (2003) 362:971-82. doi:10.1016/S0140-6736(03)14368-1

16. Emslie-Smith AM, Arahata K, Engel AG. Major histocompatibility complex class I antigen expression, immunolocalization of interferon subtypes, and T cell-mediated cytotoxicity in myopathies. Hum Pathol (1989) 20:224-31. doi:10.1016/0046-8177(89)90128-7 
17. McDouall RM, Dunn MJ, Dubowitz V. Expression of class I and class II MHC antigens in neuromuscular diseases. J Neurol Sci (1989) 89:213-26. doi:10.1016/0022-510X(89)90023-3

18. Radke J, Pehl D, Aronica E, Schonenberg-Meinema D, Schneider U, Heppner FL, et al. The lymphoid follicle variant of dermatomyositis. Neurol Neuroimmunol Neuroinflamm (2014) 1:e19. doi:10.1212/NXI.0000000000 000019

19. Ghirardello A, Bassi N, Palma L, Borella E, Domeneghetti M, Punzi L, et al. Autoantibodies in polymyositis and dermatomyositis. Curr Rheumatol Rep (2013) 15:335. doi:10.1007/s11926-013-0335-1

20. Selva-O'Callaghan A, Labrador-Horrillo M, Solans-Laque R, Simeon-Aznar CP, Martinez-Gomez X, Vilardell-Tarres M. Myositis-specific and myositis-associated antibodies in a series of eighty-eight Mediterranean patients with idiopathic inflammatory myopathy. Arthritis Rheum (2006) 55:791-8. doi:10.1002/art.22237

21. Trallero-Araguas E, Rodrigo-Pendas JA, Selva-O'Callaghan A, MartinezGomez X, Bosch X, Labrador-Horrillo M, et al. Usefulness of anti-p155 autoantibody for diagnosing cancer-associated dermatomyositis: a systematic review and meta-analysis. Arthritis Rheum (2012) 64:523-32. doi:10.1002/ art.33379

22. Fujimoto M, Hamaguchi Y, Kaji K, Matsushita T, Ichimura Y, Kodera M, et al. Myositis-specific anti-155/140 autoantibodies target transcription intermediary factor 1 family proteins. Arthritis Rheum (2012) 64:513-22. doi:10.1002/ art.33403

23. Amemiya K, Semino-Mora C, Granger RP, Dalakas MC. Downregulation of TGF-betal mRNA and protein in the muscles of patients with inflammatory myopathies after treatment with high-dose intravenous immunoglobulin. Clin Immunol (2000) 94:99-104. doi:10.1006/clim.1999.4823

24. Allenbach Y, Leroux G, Suarez-Calvet X, Preusse C, Gallardo E, Hervier B, et al. Dermatomyositis with or without anti-melanoma differentiation-associated gene 5 antibodies: common interferon signature but distinct NOS2 expression. Am J Pathol (2016) 186:691-700. doi:10.1016/j.ajpath.2015. 11.010

25. Hamaguchi Y, Kuwana M, Hoshino K, Hasegawa M, Kaji K, Matsushita T, et al. Clinical correlations with dermatomyositis-specific autoantibodies in adult Japanese patients with dermatomyositis: a multicenter cross-sectional study. Arch Dermatol (2011) 147:391-8. doi:10.1001/archdermatol.2011.52

26. Betteridge ZE, Gunawardena H, Chinoy H, North J, Ollier WE, Cooper RG, et al. Clinical and human leucocyte antigen class II haplotype associations of autoantibodies to small ubiquitin-like modifier enzyme, a dermatomyositis-specific autoantigen target, in UK Caucasian adult-onset myositis. Ann Rheum Dis (2009) 68:1621-5. doi:10.1136/ard.2008.097162

27. Muro Y, Sugiura K, Akiyama M. Low prevalence of anti-small ubiquitin-like modifier activating enzyme antibodies in dermatomyositis patients. Autoimmunity (2013) 46:279-84. doi:10.3109/08916934.2012.755958

28. Labrador-Horrillo M, Martinez MA, Selva-O’Callaghan A, Trallero-Araguas E, Grau-Junyent JM, Vilardell-Tarres M, et al. Identification of a novel myositis-associated antibody directed against cortactin. Autoimmun Rev (2014) 13:1008-12. doi:10.1016/j.autrev.2014.08.038

29. Haq SA, Tournadre A. Idiopathic inflammatory myopathies: from immunopathogenesis to new therapeutic targets. Int J Rheum Dis (2015) 18:818-25. doi:10.1111/1756-185X.12736

30. Page G, Chevrel G, Miossec P. Anatomic localization of immature and mature dendritic cell subsets in dermatomyositis and polymyositis: interaction with chemokines and Th1 cytokine-producing cells. Arthritis Rheum (2004) 50:199-208. doi:10.1002/art.11428

31. Greenberg SA, Pinkus JL, Pinkus GS, Burleson T, Sanoudou D, Tawil R, et al. Interferon-alpha/beta-mediated innate immune mechanisms in dermatomyositis. Ann Neurol (2005) 57:664-78. doi:10.1002/ana.20464

32. Suarez-Calvet X, Gallardo E, Nogales-Gadea G, Querol L, Navas M, DiazManera J, et al. Altered RIG-I/DDX58-mediated innate immunity in dermatomyositis. J Pathol (2014) 233:258-68. doi:10.1002/path.4346

33. Eloranta ML, Barbasso Helmers S, Ulfgren AK, Ronnblom L, Alm GV, Lundberg IE. A possible mechanism for endogenous activation of the type I interferon system in myositis patients with anti-Jo-1 or anti-Ro 52/ anti-Ro 60 autoantibodies. Arthritis Rheum (2007) 56:3112-24. doi:10.1002/ art. 22860

34. Joseph CG, Darrah E, Shah AA, Skora AD, Casciola-Rosen LA, Wigley FM, et al. Association of the autoimmune disease scleroderma with an
immunologicresponsetocancer.Science(2014)343:152-7.doi:10.1126/science. 1246886

35. Choy EH, Hoogendijk JE, Lecky B, Winer JB. Immunosuppressant and immunomodulatory treatment for dermatomyositis and polymyositis. Cochrane Database Syst Rev (2005) 4:CD003643. doi:10.1002/14651858.CD003643. pub2

36. Marie I, Mouthon L. Therapy of polymyositis and dermatomyositis. Autoimmun Rev (2011) 11:6-13. doi:10.1016/j.autrev.2011.06.007

37. Cavarelli J, Moras D. Recognition of tRNAs by aminoacyl-tRNA synthetases. FASEB J (1993) 7:79-86.

38. Pestronk A. Acquired immune and inflammatory myopathies: pathologic classification. Curr Opin Rheumatol (2011) 23:595-604. doi:10.1097/ BOR.0b013e32834bab42

39. Aouizerate J, De Antonio M, Bassez G, Gherardi RK, Berenbaum F, Guillevin L, et al. Myofiber HLA-DR expression is a distinctive biomarker for antisynthetase-associated myopathy. Acta Neuropathol Commun (2014) 2:154. doi:10.1186/s40478-014-0154-2

40. Mescam-Mancini L, Allenbach Y, Hervier B, Devilliers H, Mariampillay K, Dubourg O, et al. Anti-Jo-1 antibody-positive patients show a characteristic necrotizing perifascicular myositis. Brain (2015) 138:2485-92. doi:10.1093/ brain/awv192

41. Allenbach Y, Guiguet M, Rigolet A, Marie I, Hachulla E, Drouot L, et al. Efficacy of rituximab in refractory inflammatory myopathies associated with anti-synthetase auto-antibodies: an open-label, phase II trial. PLoS One (2015) 10:e0133702. doi:10.1371/journal.pone.0133702

42. Andersson H, Sem M, Lund MB, Aalokken TM, Gunther A, WalleHansen R, et al. Long-term experience with rituximab in anti-synthetase syndrome-related interstitial lung disease. Rheumatology (Oxford) (2015) 54:1420-8. doi:10.1093/rheumatology/kev004

43. Bergua C, Chiavelli H, Simon JP, Boyer O, Jouen F, Stenzel W, et al. Immunemediated necrotizing myopathy. Z Rheumatol (2016) 75:151-6. doi:10.1007/ s00393-015-0029-3

44. Mammen AL. Statin-associated autoimmune myopathy. N Engl J Med (2016) 374:664-9. doi:10.1056/NEJMra1515161

45. Werner JL, Christopher-Stine L, Ghazarian SR, Pak KS, Kus JE, Daya NR, et al. Antibody levels correlate with creatine kinase levels and strength in anti-3-hydroxy-3-methylglutaryl-coenzyme A reductase-associated autoimmune myopathy. Arthritis Rheum (2012) 64:4087-93. doi:10.1002/art.34673

46. Iaccarino L, Pegoraro E, Bello L, Bettio S, Borella E, Nalotto L, et al. Assessment of patients with idiopathic inflammatory myopathies and isolated creatin-kinase elevation. Auto Immun Highlights (2014) 5:87-94. doi:10.1007/ s13317-014-0063-1

47. Liang C, Needham M. Necrotizing autoimmune myopathy. Curr Opin Rheumatol (2011) 23:612-9. doi:10.1097/BOR.0b013e32834b324b

48. Miller T, Al-Lozi MT, Lopate G, Pestronk A. Myopathy with antibodies to the signal recognition particle: clinical and pathological features. JNeurol Neurosurg Psychiatry (2002) 73:420-8. doi:10.1136/jnnp.73.4.420

49. Chung T, Christopher-Stine L, Paik JJ, Corse A, Mammen AL. The composition of cellular infiltrates in anti-HMG-CoA reductase-associated myopathy. Muscle Nerve (2015) 52:189-95. doi:10.1002/mus.24642

50. Christopher-Stine L, Casciola-Rosen LA, Hong G, Chung T, Corse AM, Mammen AL. A novel autoantibody recognizing 200-kd and $100-\mathrm{kd}$ proteins is associated with an immune-mediated necrotizing myopathy. Arthritis Rheum (2010) 62:2757-66. doi:10.1002/art.27572

51. Hengstman GJ, ter Laak HJ, Vree Egberts WT, Lundberg IE, Moutsopoulos HM, Vencovsky J, et al. Anti-signal recognition particle autoantibodies: marker of a necrotising myopathy. Ann Rheum Dis (2006) 65:1635-8. doi:10.1136/ard.2006.052191

52. Romisch K, Miller FW, Dobberstein B, High S. Human autoantibodies against the $54 \mathrm{kDa}$ protein of the signal recognition particle block function at multiple stages. Arthritis Res Ther (2006) 8:R39. doi:10.1186/ar1895

53. Suzuki S, Hayashi YK, Kuwana M, Tsuburaya R, Suzuki N, Nishino I. Myopathy associated with antibodies to signal recognition particle: disease progression and neurological outcome. Arch Neurol (2012) 69:728-32. doi:10.1001/archneurol.2011.1728

54. Allenbach Y, Drouot L, Rigolet A, Charuel JL, Jouen F, Romero NB, et al. Anti-HMGCR autoantibodies in European patients with autoimmune necrotizing myopathies: inconstant exposure to statin. Medicine (Baltimore) (2014) 93:150-7. doi:10.1097/MD.0000000000000028 
55. Reeves WH, Nigam SK, Blobel G. Human autoantibodies reactive with the signal-recognition particle. Proc Natl Acad Sci U S A (1986) 83:9507-11. doi:10.1073/pnas.83.24.9507

56. Bronner IM, Hoogendijk JE, Wintzen AR, van der Meulen MF, Linssen WH, Wokke JH, et al. Necrotising myopathy, an unusual presentation of a steroid-responsive myopathy. JNeurol (2003) 250:480-5. doi:10.1007/ s00415-003-1027-y

57. Dalakas MC. Immunotherapy of myositis: issues, concerns and future prospects. Nat Rev Rheumatol (2010) 6:129-37. doi:10.1038/nrrheum.2010.2

58. Kassardjian CD, Lennon VA, Alfugham NB, Mahler M, Milone M. Clinical features and treatment outcomes of necrotizing autoimmune myopathy. JAMA Neurol (2015) 72:996-1003. doi:10.1001/jamaneurol.2015.1207

59. Valiyil R, Casciola-Rosen L, Hong G, Mammen A, Christopher-Stine L. Rituximab therapy for myopathy associated with anti-signal recognition particle antibodies: a case series. Arthritis Care Res (Hoboken) (2010) 62:1328-34. doi:10.1002/acr.20219

60. Curtin D, Costigan D, McCarthy C, Jansen M, Farrell M, Reid V, et al. Novel antibody associations in immune-mediated necrotising myopathy without inflammation. Ir J Med Sci (2014). doi:10.1007/s11845-014-1207-z

61. Allenbach Y, Keraen J, Bouvier AM, Jooste V, Champtiaux N, Hervier B, et al. High risk of cancer in autoimmune necrotizing myopathies: usefulness of myositis specific antibody. Brain (2016). doi:10.1093/brain/aww054

62. Grable-Esposito P, Katzberg HD, Greenberg SA, Srinivasan J, Katz J, Amato AA. Immune-mediated necrotizing myopathy associated with statins. Muscle Nerve (2010) 41:185-90. doi:10.1002/mus.21486

63. Badrising UA, Maat-Schieman M, van Duinen SG, Breedveld F, van Doorn $\mathrm{P}$, van Engelen B, et al. Epidemiology of inclusion body myositis in the Netherlands: a nationwide study. Neurology (2000) 55:1385-7. doi:10.1212/ WNL.55.9.1385

64. Rose MR, Group EIW. 188th ENMC international workshop: inclusion body myositis, 2-4 December 2011, Naarden, The Netherlands. Neuromuscul Disord (2013) 23:1044-55. doi:10.1016/j.nmd.2013.08.007

65. Mendell JR, Sahenk Z, Gales T, Paul L. Amyloid filaments in inclusion body myositis. Novel findings provide insight into nature of filaments. Arch Neurol (1991) 48:1229-34. doi:10.1001/archneur.1991.00530240033013

66. Askanas V, Engel WK, Alvarez RB. Light and electron microscopic localization of beta-amyloid protein in muscle biopsies of patients with inclusion-body myositis. Am J Pathol (1992) 141:31-6.

67. Askanas V, Engel WK, Alvarez RB, Glenner GG. beta-Amyloid protein immunoreactivity in muscle of patients with inclusion-body myositis. Lancet (1992) 339:560-1. doi:10.1016/0140-6736(92)90388-J

68. Askanas V, Engel WK. Sporadic inclusion-body myositis: conformational multifactorial ageing-related degenerative muscle disease associated with proteasomal and lysosomal inhibition, endoplasmic reticulum stress, and accumulation of amyloid-beta42 oligomers and phosphorylated tau. Presse Med (2011) 40:e219-35. doi:10.1016/j.lpm.2010.11.024

69. Fratta P, Engel WK, McFerrin J, Davies KJ, Lin SW, Askanas V. Proteasome inhibition and aggresome formation in sporadic inclusion-body myositis and in amyloid-beta precursor protein-overexpressing cultured human muscle fibers. Am J Pathol (2005) 167:517-26. doi:10.1016/S0002-9440(10) 62994-X

70. Nogalska A, D’Agostino C, Terracciano C, Engel WK, Askanas V. Impaired autophagy in sporadic inclusion-body myositis and in endoplasmic reticulum stress-provoked cultured human muscle fibers. Am J Pathol (2010) 177:1377-87. doi:10.2353/ajpath.2010.100050

71. Dubourg O, Wanschitz J, Maisonobe T, Behin A, Allenbach Y, Herson S, et al. Diagnostic value of markers of muscle degeneration in sporadic inclusion body myositis. Acta Myol (2011) 30:103-8.

72. Brady S, Squier W, Sewry C, Hanna M, Hilton-Jones D, Holton JL. A retrospective cohort study identifying the principal pathological features useful in the diagnosis of inclusion body myositis. BMJ Open (2014) 4:e004552. doi:10.1136/bmjopen-2013-004552

73. Arahata K, Engel AG. Monoclonal antibody analysis of mononuclear cells in myopathies. I: quantitation of subsets according to diagnosis and sites of accumulation and demonstration and counts of muscle fibers invaded by T cells. Ann Neurol (1984) 16:193-208. doi:10.1002/ana.410160206

74. van der Pas J, Hengstman GJ, ter Laak HJ, Borm GF, van Engelen BG. Diagnostic value of MHC class I staining in idiopathic inflammatory myopathies. J Neurol Neurosurg Psychiatry (2004) 75:136-9.
75. Benveniste O, Stenzel W, Hilton-Jones D, Sandri M, Boyer O, van Engelen BG. Amyloid deposits and inflammatory infiltrates in sporadic inclusion body myositis: the inflammatory egg comes before the degenerative chicken. Acta Neuropathol (2015) 129:611-24. doi:10.1007/s00401-015-1384-5

76. Dalakas MC, Koffman B, Fujii M, Spector S, Sivakumar K, Cupler E. A controlled study of intravenous immunoglobulin combined with prednisone in the treatment of IBM. Neurology (2001) 56:323-7. doi:10.1212/WNL.56.3.323

77. Badrising UA, Maat-Schieman ML, Ferrari MD, Zwinderman AH, Wessels JA, Breedveld FC, et al. Comparison of weakness progression in inclusion body myositis during treatment with methotrexate or placebo. Ann Neurol (2002) 51:369-72. doi:10.1002/ana.10121

78. Rutkove SB, Parker RA, Nardin RA, Connolly CE, Felice KJ, Raynor EM A pilot randomized trial of oxandrolone in inclusion body myositis. Neurology (2002) 58:1081-7. doi:10.1212/WNL.58.7.1081

79. Muscle Study G. Randomized pilot trial of high-dose betaINF-1a in patients with inclusion body myositis. Neurology (2004) 63:718-20. doi:10.1212/01. WNL.0000134675.98525.79

80. Lindberg C, Trysberg E, Tarkowski A, Oldfors A. Anti-T-lymphocyte globulin treatment in inclusion body myositis: a randomized pilot study. Neurology (2003) 61:260-2. doi:10.1212/01.WNL.0000071852.27182.C7

81. Dalakas MC, Rakocevic G, Schmidt J, Salajegheh M, McElroy B, HarrisLove MO, et al. Effect of alemtuzumab (CAMPATH 1-H) in patients with inclusion-body myositis. Brain (2009) 132:1536-44. doi:10.1093/brain/ awp104

82. Haubenberger D, Bittner RE, Rauch-Shorny S, Zimprich F, Mannhalter C, Wagner L, et al. Inclusion body myopathy and Paget disease is linked to a novel mutation in the VCP gene. Neurology (2005) 65:1304-5. doi:10.1212/01. wnl.0000180407.15369.92

83. Guyant-Marechal L, Laquerriere A, Duyckaerts C, Dumanchin C, Bou J, Dugny $\mathrm{F}$, et al. Valosin-containing protein gene mutations: clinical and neuropathologic features. Neurology (2006) 67:644-51. doi:10.1212/01. wnl.0000225184.14578.d3

84. Eisenberg I, Avidan N, Potikha T, Hochner H, Chen M, Olender T, et al. The UDP-N-acetylglucosamine 2-epimerase/ $\mathrm{N}$-acetylmannosamine kinase gene is mutated in recessive hereditary inclusion body myopathy. Nat Genet (2001) 29:83-7. doi:10.1038/ng718

85. Badrising UA, Schreuder GM, Giphart MJ, Geleijns K, Verschuuren JJ, Wintzen AR, et al. Associations with autoimmune disorders and HLA class I and II antigens in inclusion body myositis. Neurology (2004) 63:2396-8. doi:10.1212/01.WNL.0000148588.15052.4C

86. Larman HB, Salajegheh M, Nazareno R, Lam T, Sauld J, Steen H, et al. Cytosolic 5'-nucleotidase 1A autoimmunity in sporadic inclusion body myositis. Ann Neurol (2013) 73:408-18. doi:10.1002/ana.23840

87. Pluk H, van Hoeve BJ, van Dooren SH, Stammen-Vogelzangs J, van der Heijden A, Schelhaas HJ, et al. Autoantibodies to cytosolic 5'-nucleotidase 1A in inclusion body myositis. Ann Neurol (2013) 73:397-407. doi:10.1002/ ana. 23822

88. Rojana-udomsart A, James I, Castley A, Needham M, Scott A, Day T, et al. High-resolution HLA-DRB1 genotyping in an Australian inclusion body myositis (s-IBM) cohort: an analysis of disease-associated alleles and diplotypes. J Neuroimmunol (2012) 250:77-82. doi:10.1016/j.jneuroim.2012. 05.003

89. Schmidt J, Barthel K, Zschuntzsch J, Muth IE, Swindle EJ, Hombach A, et al. Nitric oxide stress in sporadic inclusion body myositis muscle fibres: inhibition of inducible nitric oxide synthase prevents interleukin-1beta-induced accumulation of beta-amyloid and cell death. Brain (2012) 135:1102-14 doi:10.1093/brain/aws046

Conflict of Interest Statement: The authors declare that the research was conducted in the absence of any commercial or financial relationships that could be construed as a potential conflict of interest.

Copyright (C) 2016 Simon, Marie, Jouen, Boyer and Martinet. This is an open-access article distributed under the terms of the Creative Commons Attribution License (CC $B Y)$. The use, distribution or reproduction in other forums is permitted, provided the original author(s) or licensor are credited and that the original publication in this journal is cited, in accordance with accepted academic practice. No use, distribution or reproduction is permitted which does not comply with these terms. 